\title{
new
}

perspectives on

turkey

27 


\title{
NEW PERSPECTIVES ON TURKEY
}

\author{
Editors \\ Çağlar Keyder, SUNY-Binghamton \\ Ayşe Öncü, Sabancı University \\ Nadir Özbek, Boğaziçi University \\ Zafer Yenal, Boğaziçi University \\ Book Review Editors \\ Reşat Kasaba, University of Washington \\ Hakan Yılmaz, Boğaziçi University \\ Managing Editor \\ Tracy Lord \\ Editorial Associates
}

Fuat Keyman Koç University, Şevket Pamuk Boğaziçi University, Fikret Şenses Middle East Technical University, Faruk Tabak Georgetown University, Zafer Toprak Boğaziçi University.

New Perspectives on Turkey is a series of research papers published biannually by the Economic and Social History Foundation of Turkey (Tarih Vakfi), Valikonağı Cad., Samsun Apt. No. 57, 80220 Nişantaşı, İstanbul.

See back cover for format and submission information.

Correspondence relating to subscriptions should be sent to Tugba Özkan, Abonet: Tel: 021221001 10, Fax: 021222227 10, e-mail: abonet@abonet.net / www.abonet.net. Correspondence relating to advertising, business matters should be sent to Sales and Marketing Manager, Tarih Vakfi, Vali Konağı Cad., Samsun Apt. No. 57, 80220 Nişantaş1-İstanbul / e-mail: pazarlama@tarihvakfi.org.tr.

\section{www.npt.boun.edu.tr www.tarihvakfi.org.tr/npt}

New Perspectives on Turkey is indexed and abstracted by:

Sociological Abstracts, Historical Abstracts,

Worldwide Political Science Abstracts, Social Services Abstracts

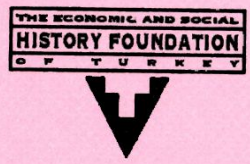

Page layout: Tarih Vakfi

Printed in Istanbul, Jenuary 2003 by Numune Matbaacillk ISBN 975-333-167-3 


\section{NEW PERSPECTIVES ON TURKEY}

No. 27

Fall 2002

\section{CONTENTS}

\section{ARTICLES}

Nationlist Dilemmas: Halide Edib on Greeks, Greece, and the West

Cornelia A. Tsakiridou

The Study of the Armenian Crisis of the late Ottoman Empire, or, "Seizing the Document by the Throat" Selim Deringil

Nostalgia for an Imaginary Home: Memory, Space, and Identity in the New Turkish Cinema $\quad F$. Asuman Suner

Business Relations into/from Gendered Social Relations:

Exchange in the Transnational Suitcase Trade

Market of Laleli

Deniz Yükseker

Imperial Center and Local Groups: Tanzimat Reforms

in the Provinces of Edirne and Ankara Yonca Köksal

\section{REVIEW ARTICLE}

State and Education in the Late Ottoman Empire:

Benjamin C. Fortna, Imperial Classroom: Islam, the State, and

Education in the Late Ottoman Empire;

Selçuk Akşin Somel, The Modernization of Public Education in the Ottoman Empire 1839-1908:

Islamization, Autocracy and Discipline

Aslı Gür

BOOK REVIEWS

Suraiya Faroqhi, Approaching Ottoman History: An Introduction to the Sources; Kate Fleet, European and Islamic Trade in the Early Ottoman State: The Merchants of Genoa and Turkey

Yael Navaro-Yashin, Faces of the State: Secularism and Public Life in Turkey Tolga Köker 